\title{
The neglected nexus between competition law and human rights: standard of proof for pecuniary penalties
}

\author{
Joshua Yeung ${ }^{1 *}$ (D) and Alex $\mathrm{CH}$ Yeung ${ }^{2 \dagger}$ (1D \\ ${ }^{1}$ Queens' College, University of Cambridge and ${ }^{2}$ Harris Manchester College, University of Oxford \\ ${ }^{\star}$ Corresponding author e-mail: ykljoshua@gmail.com
}

(Accepted 13 January 2021)

\begin{abstract}
This paper examines the standard of proof applicable in proceedings for imposing pecuniary penalties for violation of competition rules. Australia, New Zealand and the UK have chosen the civil standard. This unfortunately overlooks the safeguards required by the relevant human rights treaties in proceedings that involve the determination of a 'criminal charge'. Conversely, Hong Kong has adopted the criminal standard, which may prove unworkable in these proceedings in which economic analysis is key. After analysing whether one may set this quagmire aside by asserting that these proceedings do not involve the determination of a criminal charge, it will be argued that the more plausible solution is to accept the criminal charge characterisation, limit the civil standard to the effects-based elements of the charge and apply the criminal standard to other elements. This will achieve a permissible proportionate derogation from the human rights safeguards. Similar bifurcated models have been adopted for charges such as public nuisance and harassment, and have successfully withstood human rights challenges.
\end{abstract}

Keywords: competition law; human rights; standard of proof; pecuniary penalties; right to a fair trial; presumption of innocence

\section{Introduction}

The applicable standard of proof for competition law penalties proceedings ${ }^{1}$ is a tricky question that has consistently plagued common law jurisdictions. Most common law jurisdictions such as the UK, Australia and New Zealand have chosen to adopt the civil standard of proof. However, this is often done without considering broader human rights obligations, which generally mandate a criminal standard of proof beyond reasonable doubt due to the presumption of innocence in proceedings involving the determination of a criminal charge. In comparison, Hong Kong has recently opted to depart from its common law counterparts, relying on human rights jurisprudence to hold that despite practical difficulties the beyond reasonable doubt standard ought to apply. ${ }^{2}$ This acknowledges the human rights obligations involved, but unfortunately leads to significant practical difficulties in applying this high standard to complex economic evidence.

This paper seeks to analyse two potential solutions to this legal quagmire. First, it could be argued that competition law proceedings do not involve the determination of a criminal charge, removing the need to apply the beyond reasonable doubt standard under human rights law. This suggestion was

\footnotetext{
${ }^{\dagger}$ The authors are most grateful to the anonymous reviewers for their very insightful comments. The usual caveats apply.

${ }^{1}$ By competition law penalties proceedings, the authors refer to enforcement proceedings by national competition law authorities for competition law infringements by potential defendants. This paper does not seek to address private follow-on proceedings by victims of such infringements which are compensatory in nature.

${ }^{2}$ Competition Commission v Nutanix Hong Kong Ltd [2019] HKCT 2 at [60].

(C) The Author(s), 2021. This is an Open Access article, distributed under the terms of the Creative Commons Attribution licence (http://creativecommons.org/licenses/by/4.0/), which permits unrestricted re-use, distribution, and reproduction in any medium, provided the original work is properly cited.
} 
never considered by common law jurisdictions, which often assumed without legal argument that competition law proceedings involved the determination of a criminal charge. However, it runs into significant difficulties under the relevant human rights framework. Secondly, a proportionate derogation from the presumption of innocence can be justified by applying the balance of probabilities standard solely to effects-based economic evidence, where a criminal standard of proof could be infeasible. This mirrors other areas of the criminal law, where the standard of proof is lowered for effects-based analysis due to similar practical considerations. It obviates the need for competition law regimes to either tenuously apply the full civil standard of proof to proceedings which determine a criminal charge or suffer from the difficulties with a criminal standard of proof.

The standard of proof in major common law jurisdictions will first be summarised below, followed by an analysis of whether competition law proceedings involve the determination of a criminal charge, and finally whether a proportionate derogation by applying the civil standard of proof to effects-based economic analysis can be justified.

\section{Standard of proof in major common law jurisdictions}

To gain insight into why divergent conclusions were reached among common law jurisdictions, one must first consider how each jurisdiction arrived at its decision to adopt a particular standard of proof. The paths taken in Australia and New Zealand will first be analysed, followed by an exposition of the reasons adopted in Hong Kong and the UK.

\section{(a) Australia: civil standard}

The Australian competition rules are contained in the Trade Practices Act 1974, ${ }^{3}$ which is now rebranded as the Competition and Consumer Act 2010. ${ }^{4}$ Section 76 of the 1974 Act provides that pecuniary penalties may be imposed if the court 'is satisfied that' a person has contravened one of the competition provisions. The express words of the provision do not indicate clearly which standard of proof is to be applied.

Subsequently, the courts held that the civil standard of proof, namely the balance of probabilities, applies to competition law penalty proceedings. ${ }^{5}$ The courts' reasoning was primarily based on their view of parliamentary intent. For instance, in Heating Centre Pty Ltd $v$ Trade Practices Commission, Pincus J of the Federal Court of Australia explained that: ${ }^{6}$

[T] he position is that the Act clearly characterises proceedings under s 76 as civil ... In so doing, Parliament must be taken to have intended that the court would apply the respective standards of proof applicable to each category. It is of course, an attribute of civil proceedings that the necessary facts must be proved on the balance of probabilities, but, of course, taking into account the gravity of the matters alleged ... (Emphasis added.)

However, this explanation of the standard of proof based on Parliamentary intention faces two problems. First, it is hardly clear that Parliament 'must be taken to have intended' that the civil standard of proof is to be applied in these proceedings. When the Trade Practices Bill was tabled before Parliament, there was very enthusiastic debate on what standard of proof should be applicable, and Parliament decidedly did not come to a conclusion as to what the exact standard of proof should

\footnotetext{
${ }^{3}$ Trade Practices Act 1974 (Australia, Commonwealth).

${ }^{4}$ Competition and Consumer Act 2010 (Australia, Commonwealth).

${ }^{5}$ Trade Practices Commission v Nicholas Enterprises Pty Ltd (No 2) (1979) 40 FLR 83 at 105-106 (Fisher J); and Heating Centre Pty Ltd v Trade Practices Commission (1986) 9 FLR 153 at 160 (Pincus J). See also A Bruce Australia Competition Law (Chatswood: LexisNexis Butterworths, 3rd edn, 2019) paras 15.12-15.13.

${ }^{6}$ Heating Centre, ibid, at 160 .
} 
be. On the second reading of the Bill, Mr Bob Ellicott of the Opposition summarised his party's position on the appropriate standard of proof for competition law penalty proceedings as follows: ${ }^{7}$

Clause 76, having a quasi-criminal effect, might also be said to require proof beyond reasonable doubt. It may be that the Government would not dispute this. However, the Opposition feels that this should be expressly stated in clause 76 so that those who are charged with an offence under that section will have the benefit of that provision, namely, that if any offence is to be held against them they shall be shown to have committed it beyond reasonable doubt.

Other Members of the Opposition described the adoption of the civil standard of proof for competition law penalty proceedings as 'grossly unfair, primitive and archaic', ${ }^{8}$ and as an 'inroad' to the presumption of innocence which is the 'bulwark of [the Australian] system of criminal justice'. ${ }^{9}$ Hence, notwithstanding the Government's insistence that the civil standard of proof is appropriate for competition matters, ${ }^{10}$ the Government was eventually 'forced' ${ }^{11}$ to amend Clause 76 to its current form, where the court must be 'satisfied' that a contravention had occurred before pecuniary penalties could be ordered. The Government viewed that this formulation emphasises a 'stricter standard of proof. ${ }^{12}$ The Opposition viewed this concession as the Government's acceptance that the criminal standard applies: ${ }^{13}$

The Opposition took the view, and still takes the view, that it is fair enough that in [proceedings for pecuniary penalties] there be proof beyond reasonable doubt of any particular breach. The Government resisted that and finally was forced to amend clause 76 in such a way as to require strict proof. By that we understand the Government to mean proof beyond reasonable doubt. Apparently the Government still wishes this question to remain in a state of doubt so that the courts will have to consider it. In other words, although the Government appears to agree with us in principle it insists on a clause which will not clarify the matter at all. (Emphasis added.)

As noted by the Opposition, the requisite standard of proof was deliberately made unclear. There was indeed no consensus between the Government and the Opposition as to which standard of proof should be applicable.

The deep divide between the Opposition and the Government and its eventual muddied resolution perhaps lend strong support to the opinion of Kirby $\mathrm{J}^{14}$ and Sir John Laws ${ }^{15}$ that Parliamentary intent is a 'myth'. Parliament is a many-headed body, while intent is characteristic of a single mind. Even though only one piece of legislation was passed, each legislator may have wildly different interpretations of the same words and, by extension, would have different 'legislative intent'. More importantly for present purposes, these nuanced discussions illustrate that it is at least unclear what standard of

\footnotetext{
${ }^{7}$ Australia Parliamentary Debates, House of Representatives, 24 July 1974, 570 (Bob Ellicott).

${ }^{8}$ Australia Parliamentary Debates, House of Representatives, 7 November 1973, 3 (William McMahon).

${ }^{9}$ Australia Parliamentary Debates, Senate, 15 August 1974, 983 (Ivor Greenwood).

${ }^{10}$ See for example Australia Parliamentary Debates, House of Representatives, 24 July 1974, 589 (Kep Enderby, Minister for Manufacturing Industry).

${ }^{11}$ Australia Parliamentary Debates, House of Representatives, 23 August 1974, 1143 (Bob Ellicott).

${ }^{12}$ Australia Parliamentary Debates, House of Representatives, 23 August 1974, 1142 (Kep Enderby, Minister for Manufacturing Industry).

${ }^{13}$ Above $\mathrm{n} 11$.

${ }^{14} \mathrm{M}$ Kirby 'Towards a grand theory of interpretation: the case of statutes and contracts' (2003) 24(2) Statute Law Review 95.

${ }^{15}$ Sir J Laws 'Statutory interpretation - the myth of parliamentary intent' (Renten Lecture, London, 13 November 2017) available at http://www.statutelawsociety.co.uk/wp-content/uploads/2017/11/The-Myth-of-Parliamentary-Intent-text.pdf (last accessed 3 March 2021).
} 
proof is desired by Parliament. None of the statements quoted above were referred to in Heating Centre. ${ }^{16}$ It is, respectfully, unsafe to assume that Parliament 'must be taken to have intended' that the court should apply the civil standard of proof in these proceedings.

Secondly, Australia's obligations as a State party to the International Covenant on Civil and Political Rights ${ }^{17}$ (ICCPR) were not considered in Heating Centre. In particular, Article 14 of the ICCPR protects the right to justice and a fair trial. The United Nations Human Rights Committee (UNHRC) has explained in General Comment 32 that in proceedings determining a criminal charge, the standard of proof required by Article 14 is the criminal standard of beyond reasonable doubt', which 'ensures that the accused has the benefit of the doubt'. ${ }^{18}$ As Article 14 ICCPR does not enshrine an absolute right, it may be derogated from by proportionate legislation. Nonetheless, this demonstrates that the applicable standard of proof is not solely a matter of statutory interpretation, when Australia's obligations under the ICCPR may require the criminal standard to apply in certain proceedings. The correct approach is, thus, to first determine whether competition law penalties proceedings involve the determination of a criminal charge. It is only after making this assessment that the courts can determine whether a lower standard of proof may be applied.

The above should not be read as suggesting that Pincus J erred in Heating Centre in this regard, since General Comment 32 post-dated Heating Centre by some 20 years. However, at present, unless and until the Australian courts have considered whether competition law penalties proceedings involve the determination of a criminal charge, it would be precarious to simply assume that the applicable standard of proof is the civil standard.

\section{(b) New Zealand: civil standard}

In stark contrast with its Australian counterpart, the New Zealand competition legislation, the Commerce Act 1986, is much clearer in its prescription of the standard of proof. Section 79A of the 1986 Act provides explicitly that in competition law penalty proceedings, 'the standard of proof is the standard of proof applying in civil proceedings'. ${ }^{19}$

Although there may be no question of Parliamentary intent here, the New Zealand position shares the same mistake made in Australia: it did not consider New Zealand's obligations under the ICCPR. Like Australia, New Zealand is also a State party of the ICCPR. It follows that General Comment 32 and the requirement of criminal standard of proof would apply if it is found that competition law penalties proceedings involve the determination of a criminal charge. Importantly, as the UNHRC opined in Osiyuk $v$ Belarus, 'the concept of a "criminal charge" bears an autonomous meaning, independent of the categorisations employed by the national legal system of the States parties' ${ }^{20}$ Therefore, even though the New Zealand Parliament chose to characterise competition law penalties proceedings as 'civil' in nature, ${ }^{21}$ those proceedings may still be caught by General Comment 32 if it is later concluded that they involve the determination of a criminal charge. Legislative revision may be required when these proceedings have been properly characterised. ${ }^{22}$

\footnotetext{
${ }^{16}$ Heating Centre, above n 5 .

${ }^{17}$ International Covenant on Civil and Political Rights (adopted 16 December 1966, entered into force 23 March 1976) 999 UNTS 171.

${ }^{18} \mathrm{UNHCR}$ 'General comment no 32, article 14: right to equality before the courts and tribunals and to a fair trial' UN Doc CCPR/C/GC/32, para 30. See also S Joseph and M Castan The International Covenant on Civil and Political Rights: Cases, Materials and Commentary (New York: Oxford University Press, 3rd edn, 2013) at paras 14-105-14-112.

${ }^{19}$ Commerce Act 1986 (NZ), s 79A(a), inserted by Commerce Amendment Act 2008 (NZ), s 12.

${ }^{20}$ UNHRC 'Osiyuk $v$ Belarus' UN Doc CCPR/C/96/D/1311/2004 at para 7.3.

${ }^{21}$ Commerce Act 1986 (NZ), s 79B.

${ }^{22}$ For an excellent critique of the New Zealand position, see J Cooper 'Making the penalty fit the crime: the pros and cons of civil penalties as a means of enforcing commercial law' (2016) 14 Otago Law Review 213.
} 


\section{(c) Hong Kong: criminal standard}

In this respect, despite being the most 'nascent ${ }^{23}$ of the jurisdictions considered in this paper, the Hong Kong Competition Tribunal (HKCT) came much closer to the mark regarding the proper method for ascertaining what the standard of proof should be.

Similar to the Australian provisions, the Hong Kong Competition Ordinance did not explicitly provide the standard of proof for competition law penalties proceedings. ${ }^{24}$ The standard of proof thus fell to be determined by the judiciary, and the HKCT did so in its first enforcement proceedings, Competition Commission v Nutanix Hong Kong Ltd. ${ }^{25}$

Since the ICCPR also applies in Hong Kong, ${ }^{26}$ as analysed above, it must first be considered whether competition law penalties proceedings in Hong Kong involve the determination of a criminal charge within the meaning of Article 14 of the ICCPR. ${ }^{27}$ This is precisely what the HKCT did. At the outset, the HKCT immediately approved of the competition authority's acknowledgement that these proceedings involve the determination of a criminal charge. ${ }^{28}$ The only qualm with the HKCT's decision lies in the application of the criteria developed in Engel $v$ The Netherlands (No 1$)^{29}$ for ascertaining what constitutes a 'criminal charge'. Engel is a decision of the European Court of Human Rights (ECtHR) regarding the European Convention on Human Rights (ECHR). It would have been preferable if the HKCT had referred to the jurisprudence pertaining to the ICCPR specifically, such as the test laid down in Osiyuk, ${ }^{30}$ or explained why the Engel criteria would be helpful when making a similar determination under the ICCPR. The Osiyuk test, which considers the 'purpose, character and severity' of the charge, ${ }^{31}$ differs slightly from the Engel criteria, which focuses on the classification under domestic law, the nature of the offence, and the nature and severity of the potential sanction. The minor quibble aside, the general approach for determining the appropriate standard of proof is correct.

Having accepted that competition law penalties proceedings did involve the determination of a criminal charge, the HKCT then followed the earlier decision of the Hong Kong Court of Final Appeal in Koon Wing Yee $v$ Insider Dealing Tribunal, which applied the rule in General Comment 32 that the 'beyond reasonable doubt' standard must apply to all proceedings involving the determination of a criminal charge. ${ }^{32}$ This standard can be deviated from only by proportionate legislation, which sits uneasily with the competition authority's suggestion that a civil standard of proof applies to all elements of liability. ${ }^{33}$ It follows that the applicable standard of proof in competition law penalties proceedings is the 'beyond reasonable doubt' standard. ${ }^{34}$

From Nutanix, the correct steps in determining the standard of proof applicable to competition law penalties proceedings can be ascertained. The first step must be to consider whether the proceedings involve the determination of a criminal charge. If it does not, the court may apply a lower standard of proof such as the civil standard. If it does, the court must then consider whether any legislation which

\footnotetext{
${ }^{23}$ Competition Commission v W Hing Construction Ltd [2020] 2 HKLRD 1229 (W Hing Penalties Decision) at [39] (G Lam J).

${ }^{24}$ See Competition Ordinance (Cap 619) (HK), s 93.

${ }^{25}$ [2019] HKCT 2. See also M Pollard and K Gooi 'Work in progress: Hong Kong's competition law five years on' (2020) 11(7) Journal of European Competition Law \& Practice 372 at 377-378.

${ }^{26}$ In 1976, the UK's ratification was extended to Hong Kong as a British colony. Sovereignty over Hong Kong was resumed by the People's Republic of China on 1 July 1997. Earlier on 20 June 1997, the Government of the People's Republic of China notified the United Nations Secretary-General that the ICCPR would continue to be implemented in Hong Kong. The ICCPR has since been enshrined locally in Art 39 of the Basic Law of the Hong Kong Special Administrative Region and the Hong Kong Bill of Rights Ordinance (Cap 383): see J Chan 'State succession to human rights treaties: Hong Kong and the International Covenant on Civil and Political Rights' (1996) 45 International and Comparative Law Quarterly 928.

${ }^{27}$ As implemented in Arts 10 and 11 of the Hong Kong Bill of Rights: see the Hong Kong Bill of Rights Ordinance (ibid).

${ }^{28}$ Nutanix, above n 25, at [50].

${ }^{29}$ (1976) 1 EHRR 647.

${ }^{30}$ Osiyuk, above n 20.

${ }^{31}$ Ibid at para 7.3, citing UNHCR, 'Perterer v Austria' UN Doc CCPR/C/81/D/1015/2001 at para 9.2.

${ }^{32}$ (2008) 11 HKCFAR 170 at [86]-[103].

${ }^{33}$ Nutanix, above n 25, at [63], see also $R$ v Lambert [2001] UKHL 37, [2002] 2 AC 545 at [87]-[88] (Lord Hope).

${ }^{34}$ Nutanix, ibid, at [72].
} 
stipulates a civil standard of proof constitutes a proportionate derogation from Article 14 of the ICCPR. If this last question is answered affirmatively, the court may also apply the civil standard of proof.

\section{(d) UK: civil standard}

With the above framework in mind, the absurdity of the path taken in the UK is immediately apparent.

The UK adopts an 'administrative' model of competition law enforcement, whereby the national competition authority is empowered to impose penalties which are subject to appeal to the UK Competition Appeals Tribunal (UKCAT). ${ }^{35}$ The standard of proof in these appeals was authoritatively laid down in Napp Pharmaceutical Holdings Ltd $v$ Director General of Fair Trading (No 4). ${ }^{36}$ Similar to what transpired before the HKCT, the Director General in Napp accepted that competition law penalty proceedings involve the determination of a 'criminal charge' for the purposes of Article 6 of the ECHR, which enshrines the right to a fair trial and the presumption of innocence. ${ }^{37}$ However, contrary to the route taken in Hong Kong, the UKCAT held that the relevant standard of proof is the civil, rather than the criminal, standard. ${ }^{38}$

In reaching this conclusion, the UKCAT placed particular emphasis on the Strasbourg position, noting that: ${ }^{39}$

Neither the ECHR itself nor the European Court of Human Rights has laid down a particular standard of proof that must be applied in proceedings to which [Article 6] appl[ies], and still less that the standard should be that of 'proof beyond reasonable doubt', which is not a concept to be found in the domestic systems of many of the signatory States.

The UKCAT then relied on strong policy reasons which suggested that Parliament intended the civil standard to apply: ${ }^{40}$

We add that in many cases under the [Competition Act 1998] the factual issues before this Tribunal will often relate to such matters as determining the relevant market, whether dominance exists, and assessing whether conduct characterised as an 'abuse' is economically justified. Issues of that kind involve a more or less complex assessment of mainly economic data and perhaps conflicting expert evidence. It seems to us more likely that Parliament would have intended us to apply the civil standard of proof to issues of this kind, rather than the time-honoured criminal standard of 'proof beyond reasonable doubt'.

Napp has since been cited by not only the UKCAT, but also the English courts. ${ }^{41}$ Yet, the continued reliance on Napp is shadowed by two problems. To begin with, the UKCAT in Napp was right that the ECHR itself did not expressly recognise the 'beyond reasonable doubt' standard as a requirement under Article 6. However, the Strasbourg court has nevertheless stated emphatically on multiple occasions that the presumption of innocence protected by ECHR Article 6 requires that 'any doubt should benefit the accused'. ${ }^{42}$ One may argue that under this standard, the prosecuting authority is effectively

\footnotetext{
${ }^{35}$ See generally R Whish and D Bailey Competition Law (Oxford: Oxford University Press, 9th edn, 2018) pp 420-435.

${ }^{36}[2002]$ CAT 1, [2002] ECC 13.

${ }^{37}$ Ibid, at [92].

${ }^{38}$ Ibid, at [109].

${ }^{39}$ Ibid, at [102].

${ }^{40}$ Ibid, at [106].

${ }^{41}$ See for example Bookmakers Afternoon Greyhound Services Ltd v Amalgamated Racing Ltd [2008] EWHC 1978 (Ch) at [392] per Morgan J.

${ }^{42}$ Barbera $v$ Spain (1988) 11 EHRR 360 at [77]; Anghel $v$ Romania App no 28183/03 (ECtHR, 4 October 2007) at [54]; FC De La Torre and E Gippini-Fournier Evidence, Proof and Judicial Review in EU Competition Law (Cheltenham: Edward Elgar Publishing, 2017) p 31.
} 
required to eliminate any reasonable doubt before a pecuniary penalty could be ordered. In any event, where any doubt would benefit the accused, the standard contemplated by the Strasbourg court must be much higher than the civil standard of the balance of probabilities. Unfortunately, none of these cases were cited before the UKCAT in Napp.

Furthermore, in addition to being a signatory State of the ECHR, the UK is also a State party to the ICCPR. Hence, as with the jurisdictions examined above, the UK is also subject to General Comment $32^{43}$ which incorporates the 'beyond reasonable doubt' standard into Article 14 of the ICCPR. Although the ICCPR has not been domestically incorporated in its entirety, the obligations thereunder would still affect local jurisprudence in at least two ways. First, the ECHR is a 'living instrument'. ${ }^{4}$ International trends and jurisprudence would be relevant in the interpretation of the ECHR. ${ }^{45}$ Hence, the 'beyond reasonable doubt' standard may be read into Article 6 of the ECHR and, in turn, the Human Rights Act 1998. ${ }^{46}$ Secondly, in any event, '[i]nternational human rights law, whenever relevant, should have an important part to play in developments of the common law'. ${ }^{47}$ It follows that Napp must be reconsidered in light of General Comment 32, as part of the corpus of international human rights law and the international obligations accepted by the UK under the ICCPR.

The foregoing analysis shows that a comprehensive review is needed across common law jurisdictions regarding the standard of proof to be applied in competition law penalties proceedings. In Australia and New Zealand, whether these proceedings involve the determination of a criminal charge must first be considered. Although this question has been answered affirmatively in Hong Kong and the UK, the answer in both jurisdictions arose from concession by the national competition authorities, ${ }^{48}$ such that the tribunals did not enjoy full argument as to whether the criminal charge classification is correct. Finally, assuming that it is indeed right to treat these proceedings as involving the determination of a criminal charge, the courts must then consider whether any proportionate derogation from the criminal standard can be found. Compatibility with human rights treaties must be examined before one standard of proof could be preferred over another.

\section{The correct characterisation of competition law penalties proceedings}

Hence, the first issue to be considered is whether competition law penalties proceedings actually involve the determination of a criminal charge. The position in the UK and Hong Kong cannot be conclusive since this issue was conceded by competition law authorities in those jurisdictions, ${ }^{49}$ meaning that a critical examination of the underlying nature of competition law penalties proceedings has not been undertaken in common law jurisdictions.

\section{(a) Definition of a criminal charge}

The definition of a criminal charge under the ICCPR is stated in General Comment $32:^{50}$

Criminal charges relate in principle to acts declared to be punishable under domestic criminal law. The notion may also extend to acts that are criminal in nature with sanctions that, regardless

\footnotetext{
${ }^{43}$ Above $\mathrm{n} 18$.

${ }^{44}$ See Tyrer $v$ United Kingdom (1979-80) 2 EHRR 1 at [31], Marckx v Belgium (1979-80) 2 EHRR 30 and Dudgeon v United Kingdom (1982) 4 EHRR 149 for early development of the living instrument doctrine.

${ }^{45}$ See for example Goodwin v United Kingdom (2002) 35 EHRR 13 at [85] and Mamatkulov v Turkey (2005) 41 EHRR 25.

${ }^{46}$ Human Rights Act 1998 (UK), s 2(1). For a more extreme case of using the 'living instrument approach' to read words into the ECHR, see Rantsev v Cyprus and Russia (2010) 51 EHRR 1 at [277], where the word 'trafficking' was read into Art 4 of the ECHR using the living instrument approach, despite the absence of that word in the article itself.

${ }^{47}$ Reynolds $v$ Times Newspapers Ltd [2001] 2 AC 137 at 223 (Lord Cooke). See also The Rt Hon Lord Woolf et al De Smith's Judicial Review (London: Sweet \& Maxwell, 8th edn, 2018) para 5-054.

${ }^{48}$ Nutanix, above n 25, at [50]; Napp, above n 36, at [92].

${ }^{49} N a p p$, above n 36, at [94]; Nutanix, above n 25, at [50].

${ }^{50}$ Above $\mathrm{n} 18$, at [30].
} 
of their qualification in domestic law, must be regarded as penal because of their purpose, character or severity.

As analysed above, this determination was further expanded by the UNHRC to find that a criminal charge bore an 'autonomous meaning, independent of the categorisations employed by the national legal system of the States parties'. ${ }^{51}$ The rationale for this was explained by the UNHRC as follows:

Leaving State parties the discretion to transfer the decision over a criminal offence, including imposition of punishment, to administrative authorities and, thus, to avoid the application of the fair trial guarantees under article 14, might lead to results incompatible with the object and purpose of the Covenant

Thus, a state's categorisation of an offence does not dictate whether it involves the determination of a criminal charge. The three criteria of 'purpose, character or severity' must be considered instead.

As mentioned above, these criteria slightly differ from the corresponding legal regime under Article 6 ECHR. As held in Engel, the latter determination looks at: (1) the classification of a norm under domestic law; (2) the nature of the offence; and (3) the nature and severity of the penalty. ${ }^{52}$ The first criterion similarly only serves as a starting point and plays a less important role. ${ }^{53}$ The second criterion considers the nature of the offence, in particular whether it is 'dissuasive and repressive'. ${ }^{54}$ The third criterion examines the penalty involved and whether the consequences are sufficiently severe. Although technically the satisfaction of one criterion suffices to render the proceedings criminal, the overlap between the second and third criteria often means that they are considered cumulatively by the courts. ${ }^{55}$

The specific consideration of whether competition law penalties proceedings involve the determination of a criminal charge has not been done by the UNHRC under the ICCPR framework. However, given the similarities in the framework for determination under the ICCPR and ECHR, as evidenced by the UNHRC's previous reliance on decisions under the ECHR framework, ${ }^{56}$ such analogous decisions can help inform the likely outcome of this question.

\section{(b) Lessons from Brussels}

Although there was no argument on this issue in common law jurisdictions, the European Court of Justice (ECJ) has applied the ECHR framework to hold that competition law penalties proceedings for anti-competitive conduct do involve a determination of a criminal charge. Admittedly, the ECtHR is the primary court that determines human rights matters under the ECHR, rather than the ECJ. However, the ECJ's decisions apply with equal logical force, and also contain the clearest exposition of the rationale behind this determination. To this end, as stated in Advocate General Sharpston's Opinion in KME Germany: ${ }^{57}$

In the light of those criteria, I have little difficulty in concluding that the procedure whereby a fine is imposed for breach of the prohibition on price-fixing an marketsharing agreements in Article 81(1) EC falls under the 'criminal head' of Article 6 ECHR as progressively defined by the

\footnotetext{
${ }^{51}$ Osiyuk, above n 20, at [7.3]; UNHRC 'EV v Belarus' UN Doc CCPR/C/112/D/1989/2010 at [6.4]-[6.6].

${ }^{52}$ Above n 29.

${ }^{53}$ Adolf $v$ Austria App no 8269/78 (ECtHR, 23 March 1982) at [30]; Jussila v Finland App no 73053/01 (ECtHR, 23 November 2006) at [37].

${ }^{54}$ Ozturk v Germany App no 8544/79 (ECtHR, 21 February 1984) at [53].

${ }^{55}$ Janosevic $v$ Sweden App no 34619/97 (ECtHR, 23 July 2002) at [67]; Ziliberberg $v$ Moldova App no 61821/00 (ECtHR, 1 May 2005) at [31].

${ }^{56}$ UNHRC, 'Tarlue $v$ Canada' UN Doc CCPR/C/95/D/1551/2007 at [4.9], [7.4].

${ }^{57}$ Case C-272/09, P KME Germany and Others v Commission (GC, 8 December 2011), Opinion of AG Sharpston at [64].
} 
European Court of Human Rights. The prohibition and the possibility of imposing a fine are enshrined in primary and secondary legislation of general application; the offence involves engaging in conduct which is generally regarded as underhand, to the detriment of the public at large, a feature which it shares with criminal offences in general and which entails a clear stigma; a fine of up to $10 \%$ of annual turnover is undoubtedly severe, and may even put an undertaking out of business; and the intention is explicitly to punish and deter, with no element of compensation for damage.

Similarly, Advocate General Bo in ThyssenKrupp Nirosta GmbH referred to the purpose of competition law penalties proceedings and the potential size of fines in reaching an identical conclusion: ${ }^{58}$

While this procedure is not stricto sensu a criminal matter, it is none the less quasi-criminal in nature. The fines referred to in Article 23 of Regulation No 1/2003 are comparable in nature and size to criminal penalties and the Commission's role, given its investigatory, examination and decision-making functions, is primarily one typical of criminal proceedings against undertakings. In my view, the procedure is therefore covered by 'criminal' within the meaning of Article 6(1) of the European Convention for the protection of human rights and fundamental freedoms and must therefore be subject to the guarantees provided for by the criminal justice component of that provision.

[...]

Indeed, given the aim of competition law (namely to protect economic public policy), the nature of the fines (both preventive and punitive in effect, with no element of compensation for damage) and their size (financial penalty of a high amount), such proceedings must, according to the European Court of Human Rights, be subject to the guarantees provided for in Article 6 ECHR.

Although these authorities are from the auspices of the European Union, the same points can be made regarding the common law jurisdiction examined above. In particular, the fines for competition law infringements within these jurisdictions are similarly large, and the deterrent function of competition law penalties proceedings has been repeatedly emphasised in all four common law jurisdictions examined above. ${ }^{59}$ This demonstrates that competition law penalties are not compensatory in nature, thus competition law penalties proceedings probably involve the determination of a criminal charge. ${ }^{60}$

\section{(c) Doubts from Strasbourg and beyond}

The ECtHR's previous decision in OOO Neste St Petersburg and Others $v$ Russia potentially casts doubt on this position. In that case, the ECtHR held that certain competition law penalties proceedings in Russia failed the second and the third limbs of the Engel criteria: ${ }^{61}$

\footnotetext{
${ }^{58}$ Case C-352/09, ThyssenKrupp Nirosta v Commission [2001] ECR I-02359, Opinion of AG Bot, at [49]-[50].

${ }^{59}$ W Hing Penalties Decision, above n 23, at [37]; Competition and Markets Authority, CMA's Guidance as to the Appropriate Amount of a Penalty (CMA73, 2018) at para 1.4; NW Frozen Foods Pty Ltd v ACCC (1996) 71 FCR $285 ; 141$ ALR 640; [1997] ATPR 41-546 per Burchett and Kiefel JJ; Commerce Commission v Koppers Arch Wood Protection (NZ) Ltd (2006) 11 TCLR 581 (HC) at [18], [30].

${ }^{60}$ The consideration of EU jurisprudence under this section is limited to the issue of whether competition law proceedings involve a civil or criminal charge. The separate issue of the standard of proof in such proceedings is unclear and academically contested (see P Hellström 'A uniform standard of proof in EU competition proceedings' in CD Ehlermann and M Marquis (eds) European Competition Law Annual 2009: Evaluation of Evidence and its Judicial Review and Competition Cases (Oxford: Hart Publishing, 2011) p 147; E Gippini-Fournier 'The elusive standard of proof in EU competition cases' (2010) 33(2) World Competition 187; D Bailey 'Standard of proof in EC merger proceedings: a common law perspective' (2003) 40 Common Market Law Review 845), but will be further analysed below. For a recent statement that the standard of proof has 'no essential difference' with the beyond reasonable doubt standard, see De La Torre and Gippini-Fournier, above n 42, p 38 .

${ }^{61}$ OOO Neste St Petersburg App no 69042/01 (ECtHR, 3 June 2004) at p 10.
} 
In this connection, the Court observes, first, that the Competition Law applies only to 'relations which influence competition in commodity markets' (section 2), and therefore is of a restricted, not universal, application.

Secondly, the powers of antimonopoly authorities, as set out in section 12 of the Law, are aimed at prevention of disturbances of competition and its restoration if disturbances take place. It does not appear that the main goal of the process is to punish or deter offenders. Even though section 12-4 of the Law empowers the antimonopoly bodies to impose administrative sanctions, it follows from section 23 that these sanctions are imposed for obstructing the authorities' investigation, and do not serve as punishment for substantive antimonopoly violations.

Thirdly, pursuant to section 6-4 of the Law, certain types of monopolistic behaviour may even be authorised by the State if proven to serve common good. Genuinely criminal behaviour is not usually subject to such utilitarian justification.

Lastly, freedom of market competition is a relative, situational value and encroachments on it are not inherently wrong in themselves

[...]

As to the third criterion, the Court notes that section 6-1 of the Competition Law, under which the applicant companies were charged, does not provide for any specific sanctions as such. Offenders must, nevertheless, comply with orders issued by the TU MAP pursuant to section 12 of the Law. These orders range from a simple warning to stop monopolistic activity to compulsory division of the company. In the Court's opinion these powers of the TU MAP belong to regulatory field. So does the confiscation of unlawfully gained profit, to which the applicant companies were subjected. The Court considers that this order is intended as pecuniary compensation for damage rather than as a punishment to deter re offending (see, by contrast, Bendenoun $v$ France, judgment of 24 February 1994, Series A no. 284, $\$ 47$ ).

Having regard to these factors, the Court concludes that the applicant companies were not 'charged with a criminal offence' for the purposes of Article 6. Accordingly, this Article is not applicable.

Three points must be noted when considering this decision. First, the unique circumstances of the competition law regime in Neste limits the extent to which it could be applied to competition law regimes generally. The Russian competition law provisions in Neste only applied to undertakings which influenced the commodities market, instead of being generally applicable. ${ }^{62}$ This specific factor runs contrary to the second Engel criterion, which requires legal rules involving a criminal charge to be generally binding and not directed against any specific group. ${ }^{63}$ The applicability of the 'isolated interpretation' in Neste to wider competition law regimes that govern all undertakings is thus questionable. ${ }^{64}$

Secondly, the ECtHR's determination in Neste that 'certain types of monopolistic behaviour may even be authorised by the state to serve the common good' militated against a criminal charge could be interpreted to mean that other competition law regimes with similar efficiency defences should not be classified as criminal. ${ }^{65}$ However, as stated by Advocate General Sharpston in KME Germany:

Admittedly, in that decision the European Court of Human Rights also stressed that certain types of monopolistic behaviour may be authorised if proven to serve the common good (a possibility which is available under Article 85(3) EC, at least in theory, even for prohibited price-fixing and market-sharing agreements), whereas genuinely criminal behaviour is not usually subject to such

\footnotetext{
${ }^{62} \mathrm{Ibid}$, at p 5.

${ }^{63}$ Bendenoun v France App no 12547/86 (ECtHR, 24 February 1994) at [47].

${ }^{64}$ ThyssenKrupp Nirosta, above n 58, at fn 49-50. Admittedly, the restrictive factual circumstances in Neste could apply to segments of competition law regimes that only affect a specific subset of undertakings, such as the 'Merger Rule' in Hong Kong that only affects the telecommunications industry: Competition Ordinance (Cap 619) (HK), Sch 7, s 4. However, beyond these unique circumstances, Neste does not seem to be of general application.

${ }^{65}$ Competition Ordinance (Cap 619) (HK), Sch 1, s 1; Competition Act 1998 (UK), s 9.
} 
utilitarian justification; and that freedom of market competition is a relative, situational value, encroachments on which are not inherently wrong in themselves. As regards the first of those considerations, however, I would point out - with all due respect to the European Court of Human Rights - that it is not difficult to find undeniably criminal conduct which can none the less be authorised in appropriate circumstances. The possession of firearms may be a criminal offence in general but authorised in certain situations for public protection; the sale of certain drugs may be a criminal offence in general but authorised.

Thus, although the ECtHR in Neste determined that the existence of efficiency defences ran contrary to a criminal charge classification, this is questionable given that similar utilitarian exceptions exist within the criminal law. Further, given that the Engel criteria has led to 'a gradual broadening of the criminal head to cases not strictly belonging to the traditional categories of the criminal law, for example administrative penalties', ${ }^{66}$ the resort to strict criminal law analogies in Neste seems unconvincing.

Thirdly, the ECtHR's observation in Neste that the 'confiscation of unlawfully gained profit' under competition law penalties proceedings was 'intended as pecuniary compensation' and thus failed to satisfy the third Engel criterion is similarly problematic. The confiscation of unlawfully gained profit exactly creates the deterrence needed to discourage anti-competitive conduct. ${ }^{67}$ It is also unclear how this confiscation is compensatory, since there is no evidence to show that the seized profits go back to the pockets of wronged victims, which in competition law penalties proceedings are likely to be numerous. The confiscated profits likely remain with the state instead, as evidenced by the existence of separate compensatory follow-on proceedings for victims within competition law regimes. ${ }^{68}$ This therefore serves a deterrent rather than compensatory purpose, ${ }^{69}$ which instead further supports the proposition that competition proceedings involve the determination of a criminal charge.

One final argument contrary to the proposition that competition law penalties proceedings do involve the determination of a criminal charge could be that the pecuniary penalties imposed are comparatively low. For instance, in both Hong Kong and the UK, a pecuniary penalty imposed may not exceed $10 \%$ of the turnover of the undertaking concerned for the relevant years. ${ }^{70}$ Some have argued that this renders competition law penalties to be of a 'relatively low level of severity.' ${ }^{71}$ Conversely, Advocate General Sharpston did argue that these penalties nonetheless meet the requisite threshold of severity, since 'a fine of up to $10 \%$ of annual turnover is undoubtedly severe, and may even put an undertaking out of business'.

With great respect, Advocate General Sharpton's suggestion seems to be slightly exaggerated, and there was no evidence in the appended footnotes to support this proposition. ${ }^{72}$ The severe consequences envisioned are especially unlikely due to the general relevance of the financial position of a firm in determining the amount of a penalty, ${ }^{73}$ along with the existence of financial hardship defences to competition law penalties. ${ }^{74}$

\footnotetext{
${ }^{66}$ Jussila, above n 53, at [43].

${ }^{67} \mathrm{~K}$ Yeung 'Quantifying regulatory penalties: Australian competition law penalties in perspective' (1999) 23 Melbourne University Law Review 440 at 448-449; WPJ Wils 'Optimal antitrust fines: theory and practice' (2006) 29(2) World Competition 183 at $190-193$.

${ }^{68}$ Competition Ordinance (Cap 619) (HK), ss 110-112; Competition Act 1998 (UK), s 47A; Competition and Consumer Act 2010 (Australia, Commonwealth), ss 80, 82, 87; Commerce Act 1986 (NZ), s 82.

${ }^{69}$ Ozturk, above n 54, at [53]; Bendenoun, above n 63, at [47].

${ }^{70}$ Competition Ordinance (Cap 619) (HK) s 93(3)(a) and Competition Act 1998 (UK), s 36(8); see also Competition and Consumer Act 2010 (Australia, Commonwealth), s 56EV(2); Commerce Act 1986 (NZ), s 80(2B).

${ }^{71} \mathrm{KHF}$ Kwok 'The standard of proof in competition law proceedings' (2016) 132 Law Quarterly Review 541 at 546.

${ }^{72}$ KME Germany, above n 57, at [64].

${ }^{73}$ CMA's guidance, above n 59, at [2.23]; W Hing Penalties Decision, above n 23, at [30], [59]; Australian Competition and Consumer Commission v Australia and New Zealand Banking Group Ltd [2016] FCA 1516 at [88], [91]; Kwok, above n 71, at 545-546.

${ }^{74}$ GF Tomlinson Group Ltd \& Others v Office of Fair Trading [2011] CAT 7 at [235]; CMA's guidance, above n 59, at para 2.33; W Hing Penalties Decision, above n 23, at [118]-[122]; Australian Competition and Consumer Commission v Renegade Gas Pty Ltd (trading as Supagas NSW) [2014] FCA 1135 at [95]-[96].
} 
Nonetheless, the relatively low amount of pecuniary penalties does not convincingly bar the classification of competition law penalties proceedings as determining a criminal charge, since the relative seriousness of a sanction 'cannot deprive an offence of its inherently criminal character'. ${ }^{75}$ Moreover, given that the severity of penalties are determined on a case-by-case basis and only 'rough guidelines' can be drawn from the case law, ${ }^{76}$ the existence of comparatively low penalties alone should be insufficient to affect the characterisation of competition law penalties proceedings, especially since such penalties still remain deterrent in nature.

Therefore, although the legal position as not as definitive as suggested by Advocate General Sharpston in KME Germany, competition law penalties proceedings probably involve the determination of a criminal charge under the ICCPR and ECHR.

\section{Proportionate derogation as a solution}

\section{(a) Beyond reasonable doubt as a starting point}

The correct standard of proof for competition law penalties proceedings must now be considered. As analysed above, assuming competition law penalties proceedings involve the determination of a criminal charge, due to the presumption of innocence under Article 14(2) of the ICCPR, each of the jurisdictions analysed must apply the beyond reasonable doubt standard as a starting point. ${ }^{77}$

Unfortunately, as documented above, this standard of proof runs into significant problems when applied to the effects-based economic analysis in competition law proceedings. ${ }^{78}$ The technical and complex nature of such evidence makes it difficult to apply this high standard, especially with the presence of conflicting expert opinion in these issues. This presents common law jurisdictions with the Hobson's choice identified above: under the correct human rights classification competition law penalties proceedings require the beyond reasonable doubt standard of proof, but this classification presents significant practical problems in such proceedings.

\section{(b) Proportionate derogation}

However, an exception to the application of the beyond reasonable doubt standard to proceedings determining a criminal charge lies in proportionate derogation. Although there has been significant academic discussion on the creation of procedural safeguards for similar civil proceedings that are punitive in nature, ${ }^{79}$ such as fines for breaches of director's duties, far less academic ink has been spilt on analysing such safeguards under the human rights framework.

The ability to proportionately derogate from the presumption of innocence is well-established under Article 14 of the ICCPR and Article 6 of the ECHR. ${ }^{80}$ As held in the ECtHR decision of Le Compte, VanLeuven and De Meyer $v$ Belgium, ${ }^{81}$ '[d]emands of flexibility and efficiency' may justify some departure from the requirements of the presumption of innocence. ${ }^{82}$ The test for this was stated in Janosevic $v$ Sweden as 'the means employed have to be reasonably proportionate to the legitimate aim sought to be achieved'. ${ }^{83}$

\footnotetext{
${ }^{75}$ Lauko v Slovakia App no 4/1998/907/1119 (ECtHR, 2 September 1998) at [58].

${ }^{76} \mathrm{C}$ Grabenwarter European Convention on Human Rights Commentary (Munich: CH Beck, 2014) p 111.

${ }^{77}$ General Comment No 32, above n 18, at para 30.

${ }^{78}$ Napp, above 36, at [106]; JJB Sports Plc v Office of Fair Trading [2004] CAT 17 at [193]; Kwok, above n 71, at 544-545; De La Torre and Gippini-Fournier, above n 42, p 51.

${ }^{79} \mathrm{~K}$ Mann 'Punitive civil sanctions: the middleground between the criminal and civil law' (1992) 101 Yale Law Journal 1795; A Frieberg and P O'Malley 'State intervention and the civil offense' (1984) 18 Law and Society Review 373; J Coffee 'Paradigms lost: the blurring of the criminal and civil law models - and what can be done about it' (1992) 101 Yale LJ 1875.

${ }^{80}$ Grabenwarter, above n 76, p 165; cf R Goss Criminal Fair Trial Rights: Article 6 of the European Convention on Human Rights (Oxford: Hart Publishing, 2014) pp 176-183.

${ }^{81}$ Le Compte, Van Leuven and De Meyere v Belgium (1981) 4 EHRR 1 at [51].

${ }^{82}$ See also Jussila, above n 53 , at [42],

${ }^{83}$ Janosevic, above n 55, at [101]; Västberga Taxi Aktiebolag and Vulic v Sweden App no 36985/97 (ECtHR, 23 July 2002) at [113]-[122]; Marcello Viola v Italy App no 45106/04 (ECtHR, 5 October 2006) [71]-[77]; see also Goss, above n 80, pp 18590; De La Torre and Gippini-Fournier, above n 42, pp 60-61.
} 
Similarly, with regards to the provisions of Article 14 (then Article 11) of the ICCPR, the Privy Council held in Attorney-General of Hong Kong $v$ Lee Kwong-kut ${ }^{84}$ that:

However, it should not be assumed from this statement that the comparable article in the International Covenant to article 11(1) does not permit the degree of flexibility which is normally assumed to be implicit in any provision of general application which is of the same nature as article 11(1) of the Hong Kong Bill.

$[\ldots]$

This implicit flexibility allows a balance to be drawn between the interest of the person charged and the state. There are situations where it is clearly sensible and reasonable that deviations should be allowed from the strict applications of the principle that the prosecution must prove the defendant's guilt beyond reasonable doubt.

Any such derogation from the presumption of innocence must be proportionate. ${ }^{85}$ This analysis of proportionality involves four steps: ${ }^{86}$

(a) does the measure pursue a legitimate aim;

(b) if so, is it rationally connected with advancing that aim;

(c) whether the measure is no more than necessary for that purpose; and

(d) whether a reasonable balance has been struck between the societal benefits promoted and the inroads made into the protected rights, asking in particular whether pursuit of the societal interest results in an unacceptably harsh burden on the individual.

Unfortunately, as analysed above, the common law jurisdictions have omitted to engage in a proportionality analysis when applying the civil standard of proof, simply using practical feasibility or legislative intent as justification for the derogation of fundamental human rights. This approach overlooks the significant human rights issues involved and is problematic.

\section{(c) Balance of probabilities for effects elements}

In Hong Kong, it was previously held that the complete substitution of the criminal standard of proof with a civil standard of proof would be disproportionate. ${ }^{87}$ However, the HKCT overlooked a potential solution to the double-bind examined above: the balance of probabilities standard may be applied solely to effects-based determinations in competition law penalties proceedings. This mitigates the difficulties of applying a beyond reasonable doubt standard to such determinations, which involve the analysis of complicated economic evidence, and constitutes a more proportionate derogation than a complete evisceration of the criminal standard of proof.

The suggested solution is as follows: a distinction must be drawn between the elements of conduct and effect within a competition law infringement. The former involves proof of the conduct of an undertaking and would be governed by the beyond reasonable doubt standard. Conversely, the latter concerns proof of the causation and effect of the undertaking's conduct and would be governed by the balance of probabilities standard.

This can be demonstrated with a few hypothetical situations. As Gippini-Fournier helpfully illustrates, in an allegation involving concerted practice, the act of coordination between the relevant parties would have to be proven beyond reasonable doubt, whilst the causal 'economic logic' and

\footnotetext{
${ }^{84}$ Attorney-General of Hong Kong v Lee Kwong-kut [1993] AC 951 at 968-969.

${ }^{85}$ Ibid.

${ }^{86}$ Competition Commission v W Hing Construction Co Ltd [2019] 3 HKLRD 46 (W Hing Substantive Decision) at [158]; Hysan Development Co Ltd v Town Planning Board (2016) 19 HKCFAR 372 at [134]-[135]; Bank Mellat v Her Majesty's Treasury (No 2) [2014] AC 700 at [20].

${ }^{87}$ Koon Wing Yee $v$ Insider Dealing Tribunal (2008) 11 HKCFAR 170 at [102].
} 
'detrimental consequences on competition' caused by the coordination would be proven on a balance of probabilities. ${ }^{88}$ Similarly, in a case involving a price-fixing agreement, the existence of the agreement would be a conduct element, whilst the anti-competitive effect caused by the agreement such as the removal of price competition would be an effect element. Further, in a situation involving a refusal to deal, the refusal itself would be a conduct element; whilst the reduction of downstream competitors and ensuring harm to consumers caused by the refusal would be an effect element. The balance of probabilities standard would only apply to the effect element of a competition law infringement.

The proposed solution mirrors an analogous distinction for the standard of proof adopted by the $\mathrm{EU}$ for acts and the consequences of such acts. Although the precise standard of proof in the EU is conceptually unclear, ${ }^{89}$ a higher standard of the 'only plausible explanation' is required for the proof of acts, ${ }^{90}$ while the lower standard of 'reasonable inferences' was applied to the consequences of acts such as economic consequences, since they were 'liable to be influenced by other factors' and could not be practically proven to a higher standard. ${ }^{91}$ Similarly, in cases involving merger review before the EU, differing standards of proof apply depending on whether the EU is reviewing the application of facts or the Commission's appreciation of complex economic matters. ${ }^{92}$

This solution further mirrors analogous approaches adopted for specific effects-based crimes within the criminal law, which may be difficult to demonstrate by the prosecution under a beyond reasonable doubt standard. For instance, in the UK, section 63 of the Criminal Justice and Public Order Act 1994 governs offences related to loud outdoor music gatherings, otherwise known as raves. The scope of such offences is defined as follows: ${ }^{93}$

(1) This section applies to a gathering on land in the open air of 20 or more persons (whether or not trespassers) at which amplified music is played during the night (with or without intermissions) and is such as, by reason of its loudness and duration and the time at which it is played, is likely to cause serious distress to the inhabitants of the locality...

There is thus no need to prove beyond reasonable doubt that the gathering caused actual serious distress to local inhabitants. A mere likelihood is all that is required.

The same is true for the archaic common law offence of public nuisance. In defining the elements of the offence, Lord Bingham held that: ${ }^{94}$

I would for my part accept that the offence as defined by Stephen, as defined in Archbold (save for the reference to morals), as enacted in the Commonwealth codes quoted above and as applied in the cases... referred to in paras 13 to 22 above is clear, precise, adequately defined and based on a discernible rational principle. A legal adviser asked to give his opinion in advance would ascertain whether the act or omission contemplated was likely to inflict significant injury on a

\footnotetext{
${ }^{88}$ Gippini-Fournier, above n 60, at 197-198; De La Torre and Gippini-Fournier, above n 42, pp 48-50.

${ }^{89}$ Hellström, above n 60; Gippini-Fournier, above n 60.

${ }^{90}$ Gippini-Fournier, above n 60, at 197-198; Joined cases C-89/85, C-104/85, C-114/85, C-116/85, C-117/85 and C-125/85 to C-129/85, A Ahlström Ossakeyhtiö and Others v Commission [1993] ECR I-1307, at [71], [72], [126]; Case T-36/05, Coats Holdings and Coats $v$ Commission [2007] ECR II-110, at [83]-[96].

${ }^{91}$ Case T-53/03, BPB plc v Commission [2008] ECR II-1333, [300]-[301]; Gippini-Fournier, above n 60, at 197-199; Case T-69/04, Schunk $v$ Commission [2008] ECR II-2567 at [168]-[169]; Joined Cases T-259/02 to T-264/02 and T-272/02, Raiffeisen Zentralbank Osterreich AG and Others $v$ Commission [2006] ECR II-5169 at [287]; Case T-168/01, GlaxoSmithKline v Commission [2006] ECR II-2969 at [79], [84], cf [182]-[186].

${ }^{92}$ Hellström, above n 60, at 7; B Vesterdorf 'Standard of proof in merger case: reflections in the light of recent case law of the community courts' (2005) 1(1) European Competition Journal 3, 15-19; Bailey, above n 60, at 869. The authors acknowledge the well-established difference between a standard of review in the ECJ's review of the EC's decisions and the standard of proof being argued in this paper. However, the distinctive standards required for different factual matters by the ECJ remains analogous to the authors' suggestion for common law jurisdictions.

${ }^{93}$ Criminal Justice and Public Order Act 1994 (UK), s 63.

${ }^{94} R v$ Rimmington; $R v$ Goldstein [2005] UKHL 63; [2006] 2 All ER 257 at [36].
} 
substantial section of the public exercising their ordinary rights as such: if so, an obvious risk of causing a public nuisance would be apparent; if not, not.

His Lordship again referred to the effect of the conduct causing public nuisance in terms of likelihood, rather than the certainty generally required under the beyond reasonable doubt standard.

A likelihood requirement was also introduced for the statutory offence of sending prohibited articles by post: ${ }^{95}$

A person commits an offence if he sends by post a postal packet which encloses any creature, article or thing of any kind which is likely to injure other postal packets in course of their transmission by post or any person engaged in the business of a postal operator

There is again no need for the prosecution to demonstrate with certainty the effect of injuring postal packets or other persons.

Finally, a similar approach is adopted in the statutory offence of causing harassment, alarm or distress under section 5 of the Public Order Act 1986: ${ }^{96}$

(1) A person is guilty of an offence if he-

(a) uses threatening or abusive words or behaviour, or disorderly behaviour, or

(b) displays any writing, sign or other visible representation which is threatening or abusive, within the hearing or sight of a person likely to be caused harassment, alarm or distress thereby.

The effect of the conduct in causing harassment, alarm or distress again does not have to be proven for certain; mere likelihood is sufficient. The rationale for this approach similarly lies in the practical difficulty with proving the effects of certain crimes, as explained by the UK Law Commission:

There are strong reasons of convenience for retaining an offence in this form rather than introducing a new offence with a requirement of actual outrage. Very often the main prosecution witnesses will be police officers, who are likely to become case-hardened in the course of their careers and may not be believed when they give evidence of their disgust. Conversely, it would be highly controversial to extend the offence to acts which are not likely to outrage the general public but which do outrage a particular section of the public. ${ }^{97}$

The current solution therefore mirrors analogous offences in the criminal law, where the standard of proof is lowered for specific effect-based elements of the crime.

Importantly, the solution suggested here does not concern the use of economic analysis to demonstrate whether an undertaking benefits from an efficiency exemption, which, contrary to judicial opinion, ${ }^{98}$ does not lead to significant problems. This is due to the nature of the efficiency exemption as a defence rather than part of the charge which competition authorities have to prove. ${ }^{99}$ In line with general criminal law principles, the standard of proof for a defence is not beyond reasonable doubt but merely on the balance of probabilities, since the former standard only applies to proof of the charge by the prosecution and not any defences raised by the defendant. ${ }^{100}$ Hence, the use of economic

\footnotetext{
${ }^{95}$ Postal Services Act 2000 (UK), s 85(1).

${ }^{96}$ Public Order Act 1986 (UK), s 5.

${ }^{97}$ Law Commission Simplification of Criminal Law: Public Nuisance and Outraging Public Decency (Law Com No 358, 2015) at para 3.115.

${ }^{98} \mathrm{Napp}$, above n 36, at [106]; JJB, above n 78, at [193]; Kwok, above n 71, at 545.

${ }^{99}$ Ping Europe Ltd $v$ Competition and Markets Authority [2018] CAT 13 at [107]-[108]; Sainsbury's Supermarkets Ltd v Mastercard Inc [2020] UKSC 24 at [109]; W Hing Substantive Decision, above n 86, at [204].

${ }^{100}$ General Comment No 32, above n 18 , at para 30.
} 
analysis for the purposes of efficiency defences under competition law is not problematic, as the balance of probabilities standard applies instead.

\section{(d) Proportionality of the proposed solution}

The suggested solution of determining the effect elements of competition law infringements under a balance of probabilities standard is a proportionate derogation from the presumption of innocence under the four-step test. ${ }^{101}$ The first two steps of the proportionality analysis are probably not in dispute. The lowering of the standard of proof pursues the legitimate aim of prohibiting anti-competitive conduct, and is rationally connected to this aim due to the practical difficulties identified above. ${ }^{102}$ The main issue would be determining whether the measure is no more than necessary.

Derogations from the presumption of innocence have often been proportionately justified on the basis of practical difficulties, due to the lack of 'competence of a court to assess the evidence and to rule on the accused's guilt'. ${ }^{103}$ This is well-illustrated by the existence of presumptions for certain crimes that benefit the prosecution. For instance, the ECtHR has repeatedly justified presumptions against defendants who are seen to be non-compliant with tax law due to practical considerations: ${ }^{104}$

The Court also has regard to the financial interests of the State in tax matters, taxes being the State's main source of income. A system of taxation principally based on information supplied by the taxpayer would not function properly without some form of sanction against the provision of incorrect or incomplete information, and the large number of tax returns that are processed annually coupled with the interest in ensuring a foreseeable and uniform application of such sanctions undoubtedly require that they be imposed according to standardised rules.

Further, practical considerations of 'efficiency and economy' have justified derogations such as expedited criminal proceedings with less procedural safeguards such as the absence of the accused. ${ }^{105}$ The practical difficulties with applying the beyond reasonable doubt standard to technical economic evidence similarly justify the present derogation.

Although the suggested solution itself has not been judicially tested, there are convincing reasons in favour of its proportionality.

First, a shift in evidential burden has been held to be proportionate on the basis of practical considerations. ${ }^{106}$ In comparison, the suggested solution is a less severe derogation from the presumption of innocence, since the burden of proof remains on competition authorities throughout instead of shifting to the alleged infringing party. Consequently, the suggested solution would probably be proportionate.

Secondly, the suggested derogation is proportionate within the context of competition law penalties proceedings, which 'do not concern a paradigm criminal offence punishable by imprisonment'. ${ }^{107}$ The

\footnotetext{
${ }^{101}$ W Hing Substantive Decision, above n 86, at [158]; Hysan, above n 86, at [134]-[135]; Bank Mellat, above n 86, at [20]. The authors acknowledge that the suggested solution could have other human rights implications, for instance on whether the trial itself is fair (eg under Art 6(1) ECHR). However, given that the standard of proof is primarily associated with the presumption of innocence, the primary focus of this analysis is on that limb of the right to a fair trial within the relevant human rights instruments (Art 14(2) ICCPR, Art 6(2) ECHR: see eg WA Schabas The European Convention on Human Rights: A Commentary (Oxford: Oxford University Press, 2015) p 298 ff). In any event, since the proposed solution increases the standard of proof for elements of conduct to the benefit of the alleged infringing party, this probably results in a fairer trial than the current UK position (where all elements have to be proven on the balance of probabilities) within the meaning of the relevant human rights instruments, see eg ibid, p $278 \mathrm{ff}$.

${ }^{102}$ W Hing Substantive Decision, above n 86, at [189]-[191].

${ }^{103}$ Grabenwarter, above n 76, p 167.

${ }^{104}$ Janosevic, above n 55, at [194]; Västberga, above n 83, at [114]-[122].

${ }^{105}$ Jussila, above n 51, at [42]; Hermi v Italy App no 18114/02 (EctHR, 18 October 2006) at [80]-[81]; A Mowbray 'No violations but interesting: a study of the Strasbourg Court's jurisprudence in cases where no breach of the Convention has been found' (2008) 14(2) European Public Law 237, 243-245.

${ }^{106}$ W Hing Substantive Decision, above n 86, at [204].

${ }^{107}$ Ibid, at [194].
} 
severity of the criminal charge at hand is a relevant consideration for determining proportionality, where criminal charges 'not strictly belonging to the traditional categories of criminal law' will not have guarantees 'appl[ied] with their full stringency. ${ }^{108}$ ' $[\mathrm{T}]$ he objection against derogation from the presumption of innocence is not augmented by the prospect of severe punishment following a conviction', ${ }^{109}$ which further supports the proportionality of the suggested measure.

Lastly, the fourth step of the proportionality test is likely to be satisfied, given that the current suggestion strikes a reasonable balance between the societal benefits (through resolving the abovementioned practical difficulties and enabling better competition law enforcement) and the inroads made into human rights (since the infringement on the presumption of innocence is not substantial). The lowering of the standard of proof for effects-based elements of competition law infringements is therefore probably proportionate.

\section{(e) Workability of the proposed solution}

Admittedly, one might question the practical implementation of differing standards of proof within competition law penalties proceedings. As raised by the UKCAT in JJB Sports plc $v$ Office of Fair Trading (JJB): ${ }^{110}$

We are not satisfied that it would be appropriate or even workable, as Allsports seems to suggest, to draw any distinction regarding the standard of proof between cases where the issue is apparently one of primary fact, such as whether there was a price fixing agreement, and other cases. Even in price fixing cases, the parties often rely on expert economic or econometric evidence as showing that there was no cartel. More fundamentally, it would seem to us unnecessarily complicated, and questionable under Community law, to have one standard of proof for whether there was an agreement, and a different standard of proof for all other issues such as whether the agreement 'distorted competition', or satisfied Article 81(3) or its domestic equivalent, section 9 of the Act.

However, the UKCAT in JJB failed to distinguish the use of economic evidence to demonstrate elements of conduct and elements of effect. Proof of the former probably does not rely on complex economic evidence alone; rather such evidence is often circumstantial in support of direct evidence, such as correspondence demonstrating the existence of price-sharing agreements or a refusal to deal. Competition authorities are very likely going to possess such direct evidence, given the sweeping enforcement powers that they possess to gather evidence from undertakings. ${ }^{111}$ Therefore, to the extent that economic evidence is relevant to proof of conduct, the same difficulties that justify lowering the standard of proof for effects do not analogously apply, since direct evidence exists to mitigate such difficulties. Similar practical difficulties have also not existed for the EU, which analogously implements differing standards of proof for economic evidence as analysed above.

Additionally, as acknowledged in JJB itself, the standard of proof is not a unitary concept and 'the more serious the allegation, the more cogent should be the evidence before the court concludes that the allegation is established on the preponderance of probabilities'. ${ }^{112}$ The standard of proof further differs depending on the inherent probability of the fact to be proven, as Lord Hoffmann's famous statement about the lion in the city park demonstrates. ${ }^{113}$ Therefore, the inherent 'flexibility' ${ }^{114}$ within

\footnotetext{
${ }^{108}$ Jussila, above n 53, at [43], but note Judge Loucaides' strident dissent on this point at [O-II 2]; Kammerer v Austria App no 32435/06 (ECtHR, 12 May 2010) at [26], [28].

${ }^{109} R v$ Johnstone [2003] UKHL 28 at [50]; W Hing Substantive Decision, above $\mathrm{n}$ 86, at [194].

${ }^{110} \mathrm{JJB}$, above n 78, at [194]; Kwok, above n 71, at 545 .

${ }^{111}$ Competition Ordinance (Cap 619) (HK), ss 41-42; Competition Act 1998 (UK), ss 25-29; Competition and Consumer Act 2010 (Australia, Commonwealth), Pt XII; Commerce Act 1986 (NZ), ss 98-100.

${ }^{112} J J B$, above $\mathrm{n} 78$, at [201].

${ }^{113}$ Secretary for State for the Home Department $v$ Rehman [2003] 1 AC 153 at [55]; Gippini-Fournier, above n 60, at 200; De La Torre and Gippini-Fournier, above n 42, pp 46-47; Bailey, above n 60, at 853, 886.

${ }^{114}$ Re H [1996] AC 563 at 586; B v Chief Constable of Somerset and Avon [2001] 1 WLR 640 at [30]; Gough v Chief Constable of Derbyshire Constabulary [2002] QB 1213 at [90].
} 
a civil standard of proof already leads to differing evidentiary requirements for proving different conduct. It is unclear how much more 'unnecessarily complicated' a derogation from the beyond reasonable doubt standard would be for specific types of evidence, especially due to the practical necessity of this as established above. This mirrors the suggestion for differing procedural safeguards in 'middleground' civil proceedings based on the disproportionateness of the punitive financial penalties awarded. ${ }^{115}$ Most importantly, any alleged practical difficulties in applying differing standards of proof ought not take precedence over legal principle and human rights protections, especially since the erosion of fundamental rights would harm the legitimacy of the competition law penalties regime. $^{116}$

\section{(f) Change through legislation}

Hence, common law jurisdictions ought to modify the standard of proof in competition law proceedings by allowing the economic effects of anti-competitive conduct to be proven on the balance of probabilities. This provides a unique solution to the Hobson's choice between classifying competition law penalties proceedings as involving the determination of a criminal charge and corresponding difficulties in applying the beyond reasonable doubt standard to complex economic analysis.

This derogation must be clearly prescribed by the legislature to be lawful. The principle of legality requires that such a derogation of fundamental rights cannot arise absent express words or necessary implication. ${ }^{117}$ A necessary implication differs from a reasonable implication and is one which necessarily follows from the express provisions of the statute construed in their context'. ${ }^{118}$ Hence, general or ambiguous words cannot be interpreted as derogating the basic rights of individuals.

There must, therefore, be a clear legislative pronouncement that the balance of probabilities standard applies to effects-based economic evidence in competition law penalties proceedings. Admittedly, legislative change takes significant time to implement, but this proposed solution helps common law jurisdictions resolve the abovementioned conundrum without turning a blind eye to the relevant human rights provisions or being saddled with significant evidential difficulties in proceedings.

\section{Conclusion}

As demonstrated above, most common law jurisdictions have unfortunately missed the mark in determining the standard of proof for competition law penalties proceedings. This determination clearly has significant ramifications on how such proceedings are conducted in the future. Problematically, most common law jurisdictions including the UK, Australia and New Zealand have adopted a civil standard of proof for such proceedings, despite their classification under human rights law as involving the determination of a criminal charge which gives rise to protections such as the presumption of innocence. The courts' oversight of the relevant human rights protections unfortunately puts this determination of the standard of proof on a shaky footing.

Hong Kong, despite being the most 'nascent' ${ }^{\text {'19 }}$ competition law jurisdiction, fares much better by correctly engaging in the required human rights analysis. However, it unnecessarily took on significant practical difficulties by concluding that the classification of proceedings as involving the determination of a criminal charge correspondingly required the beyond reasonable doubt standard of proof. This overlooks two potential solutions that correctly apply human rights law but avoid the practical

\footnotetext{
${ }^{115}$ Mann, above n 79, at 1872; PY Lee 'Regulating directors' duties with civil penalties: taking a leaf from Australia's book' (2006) 35(1) Common Law World Review 1, at 18; Coffee, above n 79, at 1885; Frieberg and O’Malley, above n 79 , at 387.

${ }^{116}$ Lee, above $\mathrm{n} 115$, at 18 .

${ }^{117} R v$ Secretary of State for the Home Department, ex $p$ Simms \& Another [2002] 2 AC 115 at 130D-G, 131E; $R v$ Secretary of State for the Home Department, ex p Pierson [1998] AC 539 at 575D; Coco $v$ The Queen (1993) 179 CLR 427 at 437 ; Nutanix, above n 25, at [63].

${ }^{118} R$ (on the application of Morgan Grenfell \& Co Ltd) $v$ Special Commissioner [2003] 1 AC 563 at [45]; Nutanix, above $\mathrm{n}$ 25 , at $[63]$.

${ }^{119}$ W Hing Penalties Decision, above n 23, at [39].
} 
difficulties of a higher standard of proof. The first involves questioning the underlying premise of whether competition law penalties proceedings determine a criminal charge, which is, in the authors' view, unlikely to succeed due to the deterrent purpose of pecuniary penalties under competition law. The second concerns a proportionate derogation from the beyond reasonable doubt standard of proof by allowing effects-based analysis to be proven on a balance of probabilities. This mirrors the lowering of the standard of proof for certain effects-based crimes within the general criminal law. The second solution does not overlook the requisite human rights law requirements, but significantly mitigates the practical problems with applying the beyond reasonable doubt standard to complex economic evidence, which neatly resolves the conundrum identified above.

Cite this article: Yeung J, Yeung ACH (2021). The neglected nexus between competition law and human rights: standard of proof for pecuniary penalties. Legal Studies 41, 336-354. https://doi.org/10.1017/lst.2021.8 